\title{
PENERAPAN MODEL PEMBELAJARAN KOOPERATIF DALAM MENINGKATKAN MOTIVASI SERTA KREATIVITAS DAN HASIL BELAJAR SISWA DI SMP NEGERI 5 TEBING TINGGI
}

\author{
Maringan Simbolon
}

Surel : maringansimbolon23@gmail.com

\begin{abstract}
ABSTRAK
Motivasi belajar siswa merupakan factor yang sangat menentukan keberhasilan prestasi siswa dalam belajar. Salah satu factor yang dpat meningkatkan motivasi belajar adalah penggunaan model belajar yang bervariatif dan relevan dengan pokok bahasan atau materi yang dipelajari. Untuk itulah sangat dituntut kemampuan guru dalam menggunakan berbagai model pembelajaran. Melalui Penelitian Tindakan Kelas (PTK), yang bertujuan untuk meningkatkan motivasi dan partisifasi belajar siswa untuk meningkatkan prestasi dan kreativitas belajar siswa dengan penggunaan model pembelajaran cooperative learning. Hasil penelitian menunjukkan bahwa proses pembelajaran dengan cooperative learning dapat meningkatkan motovasi dan partisifasi belajar sehingga dapat merubah paradigm belajar dari teacher centered ke student centered. Secara tidak langsung metode ini berhasil juga meningkatkan hasil atau prestasi belajar serta kreativitas siswa dalam belajar.
\end{abstract}

Kata Kunci : Pembelajaran Kooperatif, Meningkatkan motivasi dan kreativitas

\section{PENDAHULUAN}

Pelajaran geografi merupakan rumpun pelajaran Ilmu Pengetahuan Sosial. Selama ini ada semacam anggapan bahwa belajar IPS termasuk geografi identik dengan hapalan, sehingga membosankan bagi siswa, apalagi dewasa ini siswa hanya menganggap bahwa mata pelajaran rumpun IPS kurang penting dibandingkan dengan rumpun IPA. Hal ini menyebabkan motivasi untuk belajarpun menjadi rendah. Situasi diatas membuat seorang guru seringkali tidak bersemangat mengajar karena melihat anak didiknya tidak mau belajar dan ternyata masalahnya adalah anak didik tidak memiliki motivasi atau daya penggerak dalam belajar. Menghadapi situasi yang demikian, guru yang propesional harus menyadari bahwa semangat dan gairah belajar siswa tidak hanya ditentukan oleh anak didik itu sendiri, akan tetapi dirinya juga harus ikut berperan sebagai motivator. Sehubungan dengan hal tersebut seorang guru dituntut untuk menggunakan strategi pembelajaran yang bervariasi, sehingga dapat melayani perbedaan individual siswa, mengaktifkan siswa dengan guru, mendorong berkembangnya kemampuan baru, yang ada akhirnya siswa memiliki motivasi belajar yang tinggi. Hal ini seiring dengan pergeseran paradigma pendidikan yang berubah dari pola teaching (mengajar) ke learning (belajar). Oleh karena itu seorang guru sebagai pendidik perlu memiliki berbagai metodologi mengajar, karena 
Maringan Simbolon : Penerapan Model Pembelajaran ...

keberhasilan Proses Belajar Mengajar (PBM) bergantung pada cara/mengajar gurunya. Jika cara mengajar gurunya enak maka siswa akan tekun, rajin, antusias menerima pelajaran yang diberikan sehingga diharapkan akan terjadi perubahan dan tingkah laku pada siswa baik tutur katanya, sopan santunnya, motorik maupun gaya hidupnya Rendahnya motivasi dan partisifasi belajar dirasakan di SMP Negeri 5 Tebing Tinggi. Hal ini terlihat ketika guru menjelaskan materi pelajaran, tampak siswa kurang tertarik mengikuti pembelajaran yang diberikan oleh guru. Hal ini terlihat dari indikasi adanya beberapa orang siswa yang tidak serius sewaktu mendengarkan penjelasan guru seperti membuat tulisan-tulisan yang tidak berkaitan dengan materi pelajaran, berbisik-bisik dengan temannya atau bahkan kelihatan mengantuk. Perilaku tersebut tentunya berakibat pada rendahnya pemahaman siswa terhadap materi pelajaran Geografi, sehingga prestasinyapun menjadi rendah.

Kondisi tersebut salah satunya mungkin disebabkan oleh metode mengajar yang digunakan oleh guru, atau kurangnya media pembelajaran dan kurangnya guru dalam mengembangkan bahan pembelajaran. Guru hanya menggunakan metode ceramah, dengan diselingi tanya jawab yang minim, sehingga hal ini membuat siswa cepat bosan dan kurang terlibat dalam kegiatan pembelajaran. Kondisi demikian akan teratasi manakala guru berupaya untuk menentukan solusinya, yaitu mengganti model pembelajaran yang selama ini sering di gunakan.

Sebagai strategi awal biasakan dalam menyelesaikan suatu permasalahn dengan pendekatan problem solving dan biasakan siswa untuk aktif bekerjasama dalam kelompok (Cooperative Learning), (Elvi Mailani: 2016, dalam Jurnal Handayani). Salah satu model pembelajaran yang dipandang mampu mengatasi permasalahan belajar siswa di atas adalah model pembelajaran kelompok dengan strategi pembelajaran kooperatif (cooperative learning). Model pembelajaran ini berangkat dari dasar pemikiran "getting better together" yang menekankan pada pemberian kesempatan belajar yang lebih luas dan suasana yang kondusif. Strategi pembelajaran kooperatif merupakan strategi pembelajaran kelompok yang akhir-akhir inipe dianjurkan oleh para ahli. Menurut Slavin dalam Sanjaya (2006) mengemukakan dua alasan tentang pembelajaran kooperatif, pertama beberapa hasil penelitian membuktikan bahwa penggunaan pembelajaran kooperatif dapat meningkatkan prestasi siswa sekaligus dapat meningkatkan hubungan sosial, menumbuhkan sikap menerima kekurangan diri dan orang lain serta dapat meningkatkan harga diri. Kedua, pembelajaran kooperatif dapat memecahkan masalah dan mengintegrasikan pengetahuan dengan keterampilan. Dengan demikian pembelajaran 
kooperatif memiliki dampak yang positif terhadap siswa yang rendah hasil belajarnya, karena dapat meningkatkan motivasi, hasil belajar dan penyimpanan materi pelajaran yang lebih lama.

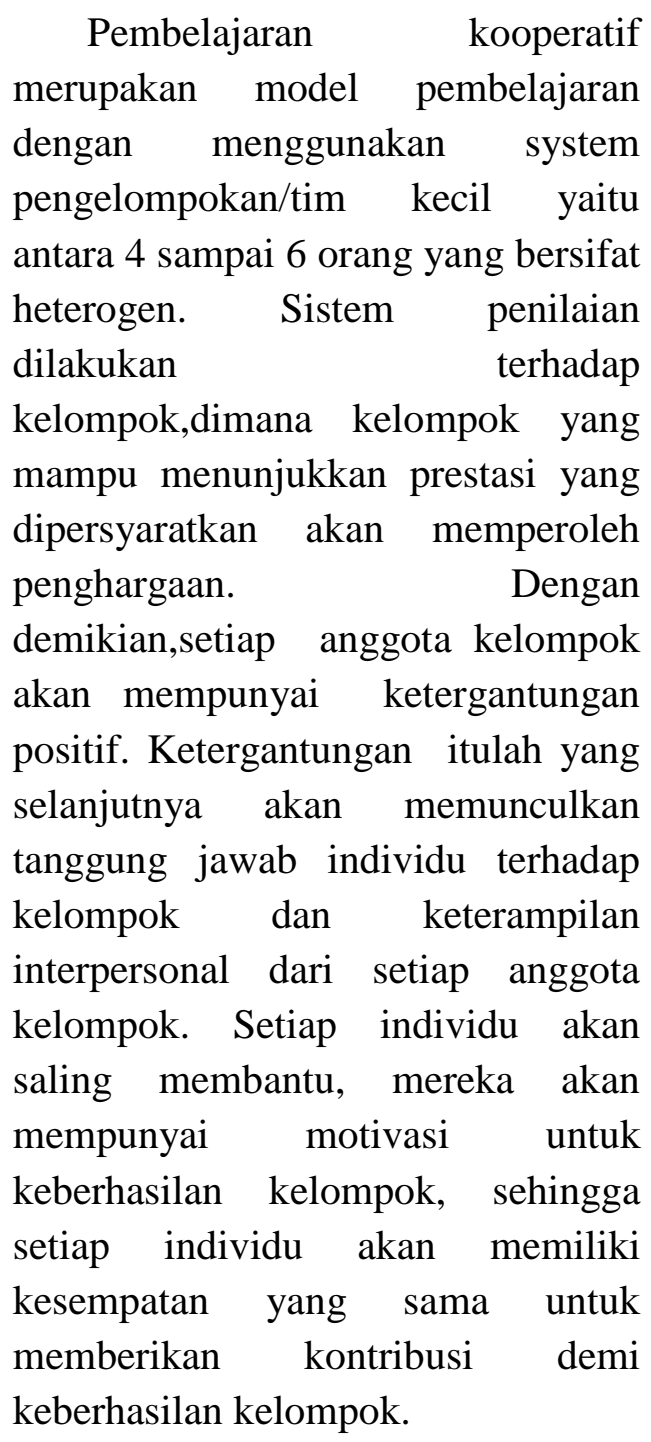

Tujuan penelitian yang ingin dicapai melalui penelitian ini adalah:

a. Menemukan model pembelajaran yang tepat untuk meningkatkan motivasi belajar siswa dalam pembelajaran Geografi b. Menemukan tingkat keberhasilan penggunaan cooperative learning dalam meningkatkan partisifasi dan kreativitasn belajar siswa dalam pembelajaran geografi.

c. Menemukan tingkat keberhasilan penggunaan cooperative learning dalam meningkatkan prestasi belajar siswa dalam pembelajaran Geografi.

d. Memberikan referensi bagi rekan guru yang lain mengenai pentingnya penggunaan cooperative learning dalam meningkatkan motivasi dan partisifasi serta kreativitas dan prestasi hasil belajar.

\section{METODE PENELITIAN}

Penelitian ini dilaksanakan di Kelas VIII-4 SMP Negeri 5 Kota Tebing Tinggi dalam materi geografi semester 1. Siswa kelas terdiri dari laki-laki 22 orang dan perempuan 16 orang. Jumlah siswa secara keseluruhan adalah 38 orang. Dipilihnya Kelas VIII-4 sebagai tempat penelitian karena diasumsi bahwa bahwa kelas ini telah memiliki kemampuan dasar keterampilan kooperatif seperti mengajukan pertanyaan, menjawab pertanyaan/ menanggapi, menyampain pendapat/ide, mendengarkan secara aktif, berada dalam tugas dan sebagainya, dalam kegiatan belajar sebelumnya. Penelitian ini berlangsung selama 1,5 bulan, dimulai awal bulan agustus tahun 2017 dan berakhir pada 
pertengahan bulan september tahun 2017.

Penelitian ini menggunakan rancangan penelitian Kelas (classroom based action research) dengan peningkatan pada unsur motivasi dan prestasi belajar prestasi belajar serta kreativitas siswa, untuk memungkinkan ditemukan dan diperolehnya efektivitas tindakan yang dilakukan. Konsep yang dipilih sebagai acuan peningkatan motivasi dan partisifasi belajar dalam mata pelajaran geografi adalah keberanian siswa untuk bertanya atau menjawab, sedangkan acuan peningkatan prestasi belajar dalam mata pelajaran geografi adalah hasil akhir nilai kognitif siswa yang harus mencapai ketuntasan. Data penelitian dikumpulkan melalui observasi dan catatan lapangan. Observasi dilakukan untuk mengetahui, motivasi, dan hasil belajar siswa dalam pembelajaran geografi sesuai dengan Rencana Pelaksanaan Pembelajaran (RPP) yang telah dirancang. Adapun catatan lapangan dilakukan untuk menggali aspekaspek lainnya yang diperlukan dalam penelitian tindakan kelas ini.

Data dikumpulkan, kemudian dipetakan dan dianalisis bersama mitra kolaborasi sejak penelitian tindakan dimulai. Selanjutnya data dikembangkan selama proses refleksi sampai proses penyusunan laporan. Teknis analisis data yang digunakan adalah model alur, yaitu reduksi data, penyajian data, dan penarikan kesimpulan (Miles \& Huberman, 1989).
Dalam penelitian ini terdapat beberapa aspek yang menjadi fokus untuk diteliti. Aspek - aspek tersebut meliputi:
1. Siswa
: a. Keaktifan
b. Motivasi
c. Kreativitas
d. Hasil belajar

2. Guru

Penggunaan model
pembelajaran
kelompok dengan
strategi
pembelajaran
kooperatif

Untuk mendapatkan data penelitian yang valid dan dapat dipertangung-jawabkan, maka dalam dalam penelitian ini digunakan beberapa instrumen pembantu, yaitu lembar observasi, dan lembar hasil tes siswa.

\section{HASIL PENELITIAN DAN PEMBAHASAN}

Tindakan siklus kesatu dilaksanakan pada awal bulan Agustus selama 2 minggu atau 2 pertemuan. Kegiatan-kegiatan yang dilakukan pada tahap perencanaan tindakan kesatu ini adalah penyusunan persiapan mengajar model pembelajaran cooperatif learning. Sebelum pelaksanaan tindakan atau siklus-siklus berlangsung maka berdasarkan temuan selama pembelajaran geografi terdapat kekurangan keterlibatan siswa dalam pembelajaran, dan siswa menjadi pasif sehingga berpengaruh terhadap hasil belajar yang diharapkan. Hal ini 
terjadi karena pembelajaran yang dikembangkan cenderung satu satu arah yaitu berpusat pada guru (teacher centered), sedangkan siswa hanya menjadi pendengar dan hanya mencatat apa yang telah disampaikan guru di depan kelas. Kondisi ini membuat siswa menjadi pasif dan motivasi untuk belajar sangat rendah, mereka terlihat mengantuk dan prestasi belajar yang diinginkanpun menjadi relatif rendah.

Dalam kondisi demikian maka kami membuat kesepakatan untuk merubah model pembelajaran yaitu dengan cooperatif learning yang diharapkan dapat melibatkan siswa lebih banyak dalam pembelajaran. Tahap perencanaan dalam model pembelajaran kooperatif dilakukan dengan berembug untuk membuat persiapan mengajar yang mencakup masalahmasalah dan langkah-langkah pembelajaran yang akan dilaksanakan yang mencerminkan model pembelajaran cooperatif learning. Sebelum pelaksanaan pembelajaran, kami juga terlebih dahulu membentuk kelompok siswa berdasarkan heterogenitas, baik jenis kelamin, prestasi akademik dan tingkah laku serta keberanian siswa. Hasilnya dari 38 siswa terentuk 8 kelompok yang terdiri dari $4-5$ orang. Rencana masalah yang akan diangkat dalam pembelajaran cooperatif learning pada tindakan kesatu adalah masalah persebaran flora maupun fauna di permukaan bumi yang terkait dengan faktorfaktor yang mempengaruhinya.
Indikator peningkatan motivasi belajar ini juga terlihat dari adanya peningkatan nilai rata-rata tiap kelompok dari sebelum menggunakan pembelajaran kooperatif dengan sesudah pembelajaran kooperatif dimana sebelumnya hasil pre tes rata-rata nilai kelas adalah 41, maka setelah pembelajaran kooperatif hasil pos tes meningkat manjadi 60,5. yang berarti mendekati nilai kriteria ketuntasan minimal.

Kegiatan pembelajaran dengan menggunakan model cooperative learning pada tindakan kedua ini sudah cukup baik. Hal-hal yang dianggap kurang baik pada tindakan pertama, seperti bagaimana guru membuka pelajaran, teknik bertanya, teknik pembentukan kelompok, penjelasan manfaat/ keuntungan dan prosedur pelaksanaan model pembelajaran cooperative learning telah diperbaiki sebagaimana yang diharapkan peneliti. Walaupun kelemahan dan kekurangan sebelumnya telah diperbaiki tidak berarti proses pembelajaran sudah baik, karena masih terdapat kelemahan yang perlu diperhatikan. Guru telah berhasil menempatkan dirinya sabagai motivador, fasilitator, mediator dan dinamisator dalam proses pembelajaran sehingga dapat memotivasi dan mengarahkan siswanya untuk memperbaiki kelemahan-kelemahan yang telah dilakukan sebelumnya, terutama dalam pelaksanaan diskusi. 
Dalam hal kegiatan membuka pelajaran, guru telah mampu memberikan penjelasan mengenai sub pokok bahasan yang akan dipelajari,dan telah pula dihubungkan dengan materi pembelajaran sebelumnya. Disamping itu guru sudah cukup baik dalam menghidupkan suasana kelas dengan menjelaskan materi pelajaran yang mengkombinasikan berbagai metode mengajar seperti ceramah dan tanya jawab. Guru telah menjalankan fungsinya sebagai seorang pengembang kurikulum, hal ini dibuktika dari penyajian materi yang tidak lagi memakai satu buku sebagai sumber relajar, Namur ada lagi buku-buku lain yang digunakan. Media peta untuk mempermudah pemahaman siswa juga mulai berfungsi dengan baik.

Dalam kagiatan inti, khususnya yang berkenaan dengan aspek-aspek kerjasama, aspek kepemimpinan dan penanaman nilainilai demokrasi telah sesuai dengan yang diharapkan, walaupun masih terdapat kelemahan yakni masih adanya siswa yang kurang mengargai temannya yang sedang berbicara walaupun sudah dilarang oleh ketua kelompoknya. Selain itu masih adanya satu kelompok yang masih belum menunjukan kepemimpinan ketua kelompoknya dalam proses diskusi, misalnya dalam membacakan atau mempresentasikan hasil belum menyebutkan pembagian tugas individu dalam jelompoknya.

Kemudian aspek yang agak lemah dalam pelaksanaan tindakan kedua ádalah masalah efisiensi waktu. Hal ini terlihat dari lambatnya penyelesaian tugas-tugas kelompok, padahal jatah waktu yang diberikan oleh guru untuk berdiskusi telah habis, Namur masih ada kelompok yang menyelesaikan tugasnya dengan terburu-buru, walaupun guru telah berulang kali mnyebutkan bahwa waktu telah habis menandakan pengerjaan kelompok pun harus dihentikan, karena harus dilanjutkan dengan presentasi kelompok.

Kemudian dalam hal
menutup pelajaran, guru telah
melakukannya dengan baik, yaitu dengan membuat beberapa kesimpulan dari materi pelajaran yang telah dipelajari. Kegiatan ini tentunya sangat penting dilakukan oleh guru supaya masalah-masalah intisari materi pelajaran akan lebih mudah diingat dan dimengerti oleh siswa. Indikator peningkatan motivasi belajar ini juga terlihat dari adanya peningkatan nilai rata-rata tiap kelompok dari siklus tindakan kesatu dan kedua pembelajaran kooperatif pada siklus kesatu, hasil pre tes rata-rata nilai kelas adalah 41 , maka setelah pembelajaran kooperatif hasil pos tes meningkat manjadi 60,5. yang berarti mendekati nilai kriteria ketuntasan minimal.

Pembelajaran pada sikslus ketiga langkah-langkah pelaksanannya sama seperti siklus pertama, tetapi ditiap langkah terjadi revisi untuk mengoptimalkan model pembelajaran kooperatif. Siklus 
ketiga ini dilaksanakan pada pertengahan bulan Agustus 2017.

Pelaksanaan pembelajaran pada siklus ketiga dilakukan dengan terlebih dahulu memberikan pre tes. Selanjutnya barulah guru menjelaskan materi yang sudah sampai pada pembahasan tentang antroposfer, dengan terlebih dahulu mengajukan pertanyaan untuk memancing siswa terkait dengan gejala kependudukan yang bisan disaksikan siswa dalam kehidupanya. Penjelasan guru tentang antroposfer yakni gejala kependudukan terlihat lebih variatif dengan diselingi tanya jawab dengan siswa. Selain itu pemberian dalam penjelasannya selalu memberi contoh-contoh konkrit yang dapat dipahami siswa. Dalam penjelasannya guru selalu menunjukan lokasi yang dijelaskan dalam sebuah peta, dan hal ini menjadi daya tarik tersendiri bagi siswa.

Setelah penjelasan materi secara singkat, langkah berikutnya kembali guru meminta siswa untuk duduk secar berkelompok dengan anggota yang sama seperti pada pembelajaran sebelumnya. Lalu guru memberikan LKS yang harus dikerjakan oleh siswa secara berkelompok. Pertemuan sebelumnya guru telah meminta siswa untuk membawa data kependudukan dari desa tempat tinggal salah satu siswa di masing masing kelompok.

Sebelum diskusi dimulai, guru menegaskan bahwa yang akan dinilai dalam diskusi adalah kekompakan kelopok, yang merupakan manfaat dari belajar dengan cooperative learning. Guru juga meminta bahwa siswa yang lebih mampu untuk selalu memberikan bantuan kepada yang kurang. Selain itu guru memberikan penegasan bahwa siapapun siswa yang ikut berpartisifasi dalam diskuci sekecil apapun pasti diberikan nilai, dan jangan pernah takut salah untuk berpendapat. Tahap berikutnya mulailah siswa bekerja dalam kelompok, untuk menjawab pertanyaan dalam LKS. Selama siswa bekerja guru terus berkeliling memantau kerja tiap kelompok, memberi pujian kepada kelompok yang aktif dan tak lupa sekecil apapun kontribusi mereka selalu dinilai. Setelah diskusi kelopok selesai, maka tiap kelompok presentasi didepan kelas, ketika siswa presentasi didepan maka semua anggota kebagian tugas, sehingga yang berbicara bukan hanya ketua kelompok. Hal ini menunjuka nilai-nilai demokratis mulai berjalan. Hal ini tidak lepas dari peranan guru yang terus memotivasi semua siswa dalam pembelajaran untuk ikut aktif. Berdasarkaan Hasil rekapitulasi nilai rata-rata di atas, maka tergambar bahwa setelah dilakukan pembelajaran dengan model cooperatif learning pada siklus ketiga maka nilai siswa sudah mengalami ketuntasan berdasarkan criteria ketuntasan minimal (KKM), yang pada siklus kesatu dan kedua belum tuntas. Nilai menunjukkan bahwa rata-rata nilai siswa hasil pos tes 
telah mencapai lenih dari 68,63. Berdasarkan hasil observasi atau pengamatan pada proses pembelajaran, dan berdasarkan hasil pos tes pada siklus tindakan ketiga, maka model pembelajaran cooperatif learning sudah berhasil dilaksanakan dengan indikator, motivasi dan partisipasi belajar meningkat serta nilai siswapun telah tuntas sesuai dengan kriteria. Hasil akhir pada siklus pembelajaran kedua juga telah menghasilkan kreativitas siswa berupa media pembelajaran yang dapat mempermudah mereka memahami persebaran flora dan fauna baik di dunia maupun di Indonesia.

\section{Pembahasan}

Motivasi belajar siswa tidak hanya ditentukan oleh siswa itu sendiri, akan tetapi juga ditentukan oleh seorang guru dalam menerapkan model pembelajaran baik didalam maupun diluar kelas. Oleh karena itu, ketika menemukan situasi motivasi belajar siswa yang rendah yang berdampak pada pestasi belajar, guru yang profesional tidak serta merta memponis bahwa siswanya bodoh, akan tetapi guru akan mencari jalan keluar dengan menerapkan berbagai model pembelajaran.

Hasil penelitian di Kelas VIII-4 SMP Negeri 5 Tebing Tinggi, menunjukan bahwa rendahnya motivasi dan hasil belajar yang selama ini hanya menggunakan model ceramah dan tanya jawab yang membosankan siswa, ternyata permasalahan dapat teratasi dengan penerapan salah satu model pembelajaran yaitu dengan model cooperative learning. Berdasarkan hasil penelitian, sistem pembelajaran dengan menggunakan model cooperative learning dapat meningkatkan efektifitas pembelajaran.

Berdasarkan data hasil penelitian, melalui penggunaan model pembelajaran cooperative learning, keseriusan siswa untuk belajar meningkat, yang ditunjukan oleh aktivitas mereka ketika guru menjelaskan dan ketika mereka diskusi, dimana mereka berusaha untuk bertanya, menjawab dan menanggapi permasalahan serta semua ikut andil menyelesaikan LKS yang ditugaskan pada setiap kelompok, sehingga jarang ditemukan siswa yang mengantuk aeperti ketika mendengar ceramah guru yang dianggap membosankan.

$$
\text { Pembelajaran }
$$

dengan

menggunakan model cooperative learning, terbukti cukup ampuh dalam mengaktifkan siswa sehingga dapat berubah pola teacher centered ke student centetered. Hal ini tidak terlepas dari strategi yang diterapkan baik dalam hal perencanaan, implementasi maupun evaluasi. Dalam proses perencanaan hasil sharing pendapat dengan rekan peneliti lain dan hasil observasi pada pembelajaran sebelumnya telah menjadi masukan yang sangat berarti dalam penyusunan perencanaan, sehingga dapat diambil tindakan kelas yang tepat dalam pembelajaran. Dalam proses implementasi atau 
pelaksanaan terhadap beberapa faktor yang mempengaruhi keberhasilan. Pertama, setiap kelompok adalah perpaduan antar anggota yang heterogen baik dari jenis kelamin maupun kemampuan akademik. Kedua, pemberian tugas yang lebih efektif yang disesuaikan dengan alokasi waktu dan sarana yang tersedia. Ketiga, kemampuan guru yang berhasil memposisikan diri sebagai fasilitator, motivator dan evaluator.

Aspek-aspek keberhasilan siswa sebagai akibat dari penggunaan cooperative learning, dapat ditinjau dari aspek keaktifan, motivasi dan hasil belajar. Ditinjau dari kreatifitas siswa, proses pembelajaran dengan cooperative learning telah mampu mengaktifkan sebagian besar siswa dalam belajar, sehingga siswa yang aktif dalam belajar bukan hanya milik siswa yang secara akademik tinggi, akan tetapi juga berhasil mengaktifkan siswa yang sebelumnya malas atau minder untuk bertanya, menjawab, atau berpendapat.

Dilihat dari aspek motivasi, model pembelajaran cooperative learning, telah mampu meningkatkan motivasi belajar siswa, sehingga mau mencari atau menanyakan jawaban dari permasalahan yang dihadapi kepada teman sekelompoknya. Motivasi tinggi juga dapat dilihat dari meningkatnya rasa keingintahuan mereka terhadap permasalahan, sehingga kadangkadang mereka kalau tidak puas bertanya di kelas, diluar kelas menanyakan kembali karena rasa penasaran terhadap fenomena geografis yang ada. Ditinjau dari aspek pretasi dan kreatifitas siswa, model pembelajaran cooperative learning, telah mampu meningkatkan hasil tes belajar siswa untuk mencapai kriteria ketuntasan minimal dibandingkan dengan hasil tes dengan model pembelajaran sebelumnya yang banyak dari siswa tidak mendapatkan nilai tuntas. Selain itu kreatifitas siswa juga muncul dengan menghasilkan beberapa hasil kreatifitas yang dapat dijadikan media pembelajaran, baik berbentuk peta persebaran flora dan fauna maupun bentuk kreatiftas lain yang dapat membantu mereka mempermudah dalam mengidentifikasi persebaran flora dan fauna. Aspek lain yang dihasilkan dari pembelajaran cooperative learning ini adalah prinsip getting better together yang memunculakn rasa kebersamaan, kekompakan rasa saling menghargai dengan berbagai perbedaan yang ada, dengan tetap bersaing secara sehat baik secara individu atau kelompok.

\section{SIMPULAN}

Dari hasil dan pembahasan penelitian seperti yang telah diungkapkan di muka secara umum dapat disimpulkan bahwa melalui penelitian tindakan kelas yang dilakukan dalam penelitian ini berhasil mencapai tujuan penelitian yaitu dapat meningkatkan motifasi dan partisipasi siswa dalam belajar geografi. 
Keberhasilan ini tercermin dari hasil evaluasi proses dan evaluasi hasil belajar. Evaluasi proses ditunjukkan dengan meningkatkannya prestasi belajar yang semua telah mencapai tuntas berdasarkan kriteria yang ditentukan, evaluasi hasil juga telah berhasil menghasilkan salah satu bentuk hasil kreatifitas sederhana yang dapat digunakan sebagai media dalam pembelajaran.

\section{DAFTAR RUJUKAN}

Arikunto, dkk. 2006. Penelitian Tindakan Kelas. Jakarta: PT Bumi Aksara.

Hisyam Zaini, Bermawy Munthe, Sekar Ayu Aryani. 2004. Strategi Pembelajaran Aktif. Yogyakarta: CTSD.

Mailani, E. 2014. Upaya Meningkatkan Kompetensi Paedagogik Guru Dalam Menyusun Rencana Pelaksanaan Pembelajaran Melalui Kegiatan Pendampingan (Mentoring). SCHOOL EDUCATION JOURNAL PGSD FIP UNIMED, 1(2).

Meilani, E. 2007. Upaya Meningkatkan Kompetensi Pedagogik Guru dalam Menyusun Rencana Pelaksanaan Pembelajaran Melalui Kegiatan Pendampingan (Mentoring). Penelitian Tindakan Kelas.

Musclich, Masnur. 2016. KTSP (Pembelajaran Berbasis Kompetensi Dan Konteksual). Jakarta: PT Bumi Aksara.
Sanjaya, Wina. 2016. Strategi Pembelajaran Berorientasi Standar Proses Pendidikan. Jakarta: Kencana Prenada Media Group.

Yasmin, Martinis. 2006. Strategi Pembelajaran Berbasis Kompetensi. Jakarta: Gaung Persada Press Jakarta. 